This article is licensed under the Creative Commons Attribution-NonCommercial 4.0 International License (CC BY-NC) (http://www.karger.com/Services/OpenAccessLicense). Usage and distribution for commercial purposes requires written permission.

\title{
Successful Treatment with Taxane- Based Chemotherapy in Advanced Sebaceous Carcinoma: A Case Report and Literature Review
}

\author{
Shuji Ota ${ }^{\mathrm{a}}$ Takahiko Sakamoto $^{\mathrm{a}}$ Ryosuke Ochiai ${ }^{\mathrm{a}}$ \\ Terunobu Haruyama $^{a} \quad$ Masashi Ishihara $^{a} \quad$ Maika Natsume $^{a}$ \\ Yoko Fukasawa $^{a}$ Shigeru Tanzawa ${ }^{a}$ Ryo Usui ${ }^{a}$ Takeshi Honda ${ }^{a}$ \\ Yasuko Ichikawa $^{a}$ Kiyotaka Watanabe ${ }^{a}$ Yuko Sasajima $^{b}$ \\ Atsushi Mizotac Nobuhiko Seki ${ }^{\mathrm{a}}$ \\ aDivision of Medical Oncology, Department of Internal Medicine, Teikyo University School \\ of Medicine, Tokyo, Japan; 'bepartment of Pathology, Teikyo University School of \\ Medicine, Tokyo, Japan; 'Department of Ophthalmology, Teikyo University School of \\ Medicine, Tokyo, Japan
}

\section{Keywords}

Sebaceous carcinoma $\cdot$ Taxane $\cdot$ Carboplatin $\cdot$ Paclitaxel $\cdot$ Docetaxel

\section{Abstract}

For sebaceous carcinoma (SC), a rare malignant tumor, no standard chemotherapy regimen for patients with distant metastasis has been studied. We experienced a case of eyelid SC with multiple lung metastases that responded to combination chemotherapy with carboplatin and paclitaxel with 11-month progression-free survival (PFS). This patient also responded to second-line treatment with docetaxel, another taxane, with 7-month PFS, resulting in at least 18 


\section{Case Reports in Oncology}

Case Rep Oncol 2019;12:47-52

DOI: $10.1159 / 000493850$

(C) 2019 The Author(s). Published by S. Karger AG, Basel www.karger.com/cro

Ota et al:: Successful Treatment with Taxane-Based Chemotherapy in Advanced

Sebaceous Carcinoma: A Case Report and Literature Review

months of survival at the time of reporting. This report shows that taxane-based chemotherapy may be effective for advanced SC, for which no standard therapy has been established.

(C) 2019 The Author(s)

Published by S. Karger AG, Basel

\section{Introduction}

Sebaceous carcinoma (SC) is a rare malignant tumor characterized by sebaceous differentiation [1]. SC is broadly classified into ocular SC, which is eyelid SC of meibomian gland or Zeis gland origin, and extraocular SC, which is SC of sebaceous gland origin [1]. Ocular SC most often originates from the meibomian gland, an independent sebaceous gland of the eyelid. By primary lesion, ocular SC accounts for approximately $75 \%$ of all cases, and extraocular SC accounts for approximately $25 \%$ [1]. While first-line therapy is surgical treatment, SC has been reported to be likely to recur or metastasize. Ginsberg et al. reported a metastasis rate of $17 \%$ and a local recurrence rate of 32\% in 142 patients with ocular SC [2], and Bailet et al. reported a metastasis rate of $21 \%$ and a local recurrence rate of $29 \%$ in 91 patients with SC of the head and neck [3]. To date, no chemotherapy regimen has been established for SC with distant metastasis. According to the Surveillance, Epidemiology, and End Results (SEER) database of the National Cancer Institute, there is no report of outcomes of chemotherapy for ocular SC with distant metastasis.

Here, we report a case of eyelid SC with lung and subcutaneous metastases that responded to both first-line and second-line treatments with taxane-based chemotherapy, resulting in at least 18 months of long-term survival at the time of reporting.

\section{Case Report}

This case was a 69-year-old female. Right eyelid tumor appeared and grew rapidly. A biopsy strongly indicated a pathological diagnosis of SC, leading to surgical resection (orbital exenteration). Given postoperative pathological findings of nests of polygonal tumor cells with highly heteromorphic nuclei and foamy lipid droplets, a final diagnosis of SC was made (Fig. 1).

Four months after surgery, multiple lung metastases (Fig. 2a) and abdominal subcutaneous metastases occurred. Chemotherapy with carboplatin (AUC5) and paclitaxel $\left(200 \mathrm{mg} / \mathrm{m}^{2}\right)$ was started as combination therapy with platinum and taxane, which have been shown to be effective for adenocarcinomas of various origins. At the start of chemotherapy, performance status (PS) was 2. After the second cycle of chemotherapy, computed tomography (CT) for response assessment revealed a partial response (PR) with an at least $50 \%$ reduction in total maximum diameter of lung (Fig. 2b) and subcutaneous metastatic nodules. A total of 7 cycles of chemotherapy was given, at 3-weeks per cycle. Hematotoxicity was Grade 3 neutropenia, but febrile neutropenia did not occur, and non-hematological toxicity was Grade 1 peripheral nerve disorder. Nonetheless, treatment was well tolerated. Combination therapy with carboplatin and paclitaxel resulted in 11-month progression-free survival (PFS). 
Later, however, multiple lung metastatic nodules increased in number and grew, and multiple brain metastases occurred. Whole-brain irradiation was performed for the treatment of multiple brain metastases, resulting in disappearance of brain metastatic nodules. After whole-brain irradiation, second-line treatment with docetaxel $\left(60 \mathrm{mg} / \mathrm{m}^{2}\right)$ alone was administered. At the start of monotherapy, PS was 2. A total of 6 cycles was given, at 3-weeks per cycle. A PR was achieved with a $45 \%$ regression of multiple lung metastatic nodules. Hematotoxicity was Grade 4 neutropenia and Grade 3 febrile neutropenia; nonetheless, treatment was well tolerated.

Chemotherapy is currently suspended at the request of the patient. However, she has survived for 18 months with 7-month PFS after the start of docetaxel.

\section{Discussion}

Sebaceous carcinoma (SC) is classified into ocular SC and extraocular SC according to the primary lesion, and Russel et al. reported that ocular SC was more malignant [4]. In addition, Rao et al. reported that, among 104 patients with eyelid SC, all of 23 (22\%) who died had distant metastasis, emphasizing the importance of distant metastasis control [5]. Our patient has successfully survived for a long period of time after combination therapy with carboplatin and paclitaxel and subsequent monotherapy with docetaxel, despite more malignant ocular SC with distant metastasis and active tumor as indicated by relapse at 4 months after surgery.

Table 1 lists case reports of chemotherapy for SC with distant metastasis [6-12]. There were three reports, including one by Jung et al., of antitumor efficacy of platinum used in combination with 5-FU [10-12]. In addition, there were two reports, including one by Husain et al., of antitumor efficacy of platinum used in combination with taxane such as docetaxel or paclitaxel $[8,9]$. Platinum and taxane have been shown to be effective for adenocarcinomas of various origins, including adenocarcinoma of unknown primary origin. In a comparative study of monotherapy with paclitaxel versus combination therapy with paclitaxel and carboplatin in lung adenocarcinoma, subgroup analysis in patients with PS 2 showed that combination therapy significantly prolonged overall survival (OS), with no significant difference in the incidence of febrile neutropenia or treatment-related mortality [13]. Therefore, our patient with PS 2, which appeared to indicate poor tolerability of combination therapy with CDDP and 5FU, received combination therapy with carboplatin and paclitaxel. Combination therapy with carboplatin and paclitaxel resulted in PR, 11-month PFS, and at least 18 months of survival at the time of reporting. In addition, this patient had a PR to second-line treatment with docetaxel, another taxane, with 7-month PFS, suggesting that SC may be sensitive to taxanes.

Due to rarity of SC, no standard chemotherapy regimen for patients with distant metastasis has been established. In clinical settings, therefore, these patients are treated based on reference to only a few case reports. Our current report shows that taxanes may be effective for SC. Availability of a wider range of effective chemotherapeutic options is beneficial for patients. Hence, this report may provide valuable information to clinicians in chemotherapy for $\mathrm{SC}$ with distant metastasis. 


\section{Statement of Ethics}

The authors have no ethical conflicts to disclose.

\section{Disclosure Statement}

The authors have no conflicts of interest to disclose.

\section{References}

1 Nelson BR, Hamlet KR, Gillard M, Railan D, Johnson TM. Sebaceous carcinoma. J Am Acad Dermatol. 1995 Jul;33(1):1-15.

2 Ginsberg J. Present status of meibomian gland carcinoma. Arch Ophthalmol. 1965 Feb;73(2):271-7.

3 Bailet JW, Zimmerman MC, Arnstein DP, Wollman JS, Mickel RA. Sebaceous carcinoma of the head and neck. Case report and literature review. Arch Otolaryngol Head Neck Surg. 1992 Nov;118(11):1245-9.

4 Russell WG, Page DL, Hough AJ, Rogers LW. Sebaceous carcinoma of meibomian gland origin. The diagnostic importance of pagetoid spread of neoplastic cells. Am J Clin Pathol. 1980 Apr;73(4):504-11.

5 Rao NA, Hidayat AA, McLean IW, Zimmerman LE. Sebaceous carcinomas of the ocular adnexa: A clinicopathologic study of 104 cases, with five-year follow-up data. Hum Pathol. 1982 Feb;13(2):113-22.

6 Koyama S, Honda T, Hayano T, Shinozaki S, Kubo K, Kobayashi T, et al. [A case of lung metastasis from Meibomian gland carcinoma of eyelid with effective chemotherapy]. Gan To Kagaku Ryoho. 1994 Dec;21(16):2809-12.

7 De Leo A, Innocenzi D, Onesti MG, Potenza C, Toscani M, Scuderi N. Extraocular sebaceous carcinoma in Muirr Torre Syndrome with unfavorable prognosis. Cancer Chemother Pharmacol. 2006 Dec;58(6):842-4.

8 Husain A, Blumenschein G, Esmaeli B. Treatment and outcomes for metastatic sebaceous cell carcinoma of the eyelid. Int J Dermatol. 2008 Mar;47(3):276-9.

9 Joshi P, Joshi A, Norohna V, Prabhash K, Kane S, D'cruz AK. Sebaceous carcinoma and systemic chemotherapy. Indian J Med Paediatr Oncol. 2012 Oct;33(4):239-41.

10 Jung YH, Woo IS, Kim MY, Han CW, Rha EY. Palliative 5-fluorouracil and cisplatin chemotherapy in recurrent metastatic sebaceous carcinoma: case report and literature review. Asia Pac J Clin Oncol. 2016 Mar;12(1):e189-93.

11 Orcurto A, Gay BE, Sozzi WJ, Gilliet M, Leyvraz S. Long-term remission of an aggressive sebaceous carcinoma following chemotherapy. Case Rep Dermatol. 2014 Mar;6(1):80-4.

12 Kumar V, Xu Y. Unusual presentation of metastatic sebaceous carcinoma and its response to chemotherapy: is genotyping a right answer for guiding chemotherapy in rare tumours? Curr Oncol. 2015 Aug;22(4):e3169.

13 Lilenbaum RC, Herndon JE 2nd, List MA, Desch C, Watson DM, Miller AA, et al. Single-agent versus combination chemotherapy in advanced non-small-cell lung cancer: the cancer and leukemia group B (study 9730). J Clin Oncol. 2005 Jan;23(1):190-6. 


\section{Case Reports in Oncology}

Ota et al.: Successful Treatment with Taxane-Based Chemotherapy in Advanced

Sebaceous Carcinoma: A Case Report and Literature Review

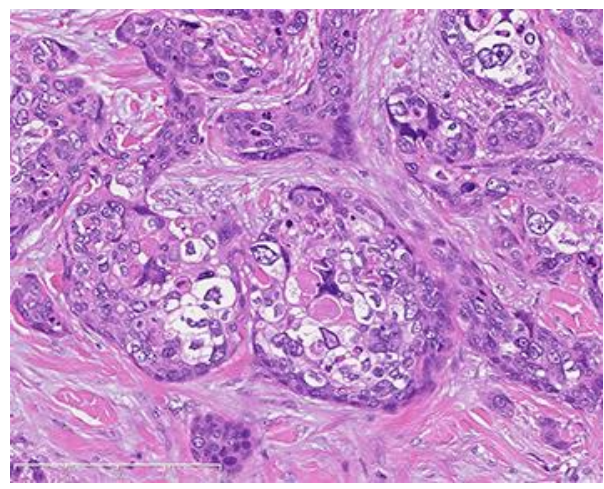

Fig. 1. In the surgical specimen, there were irregular nests of polygonal cells with heteromorphic nuclei. Some tumor cells had foamy cytoplasm, and sebaceous differentiation was observed (hematoxylin-eosin $\times 20$ ).
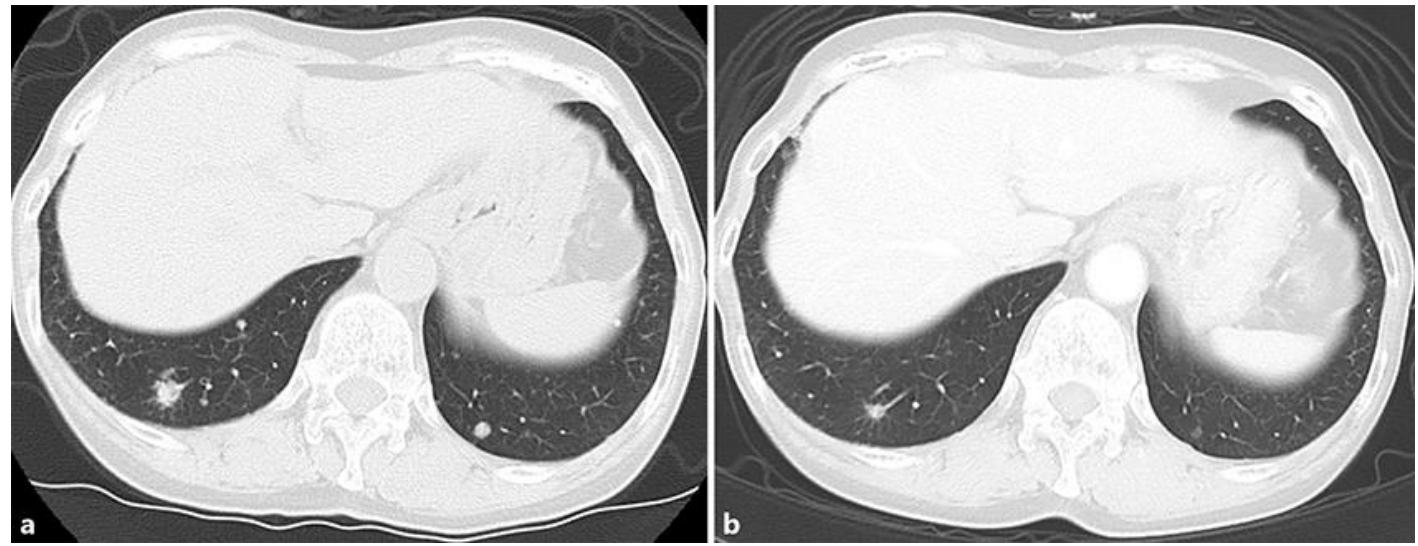

Fig. 2. a: Chest computed tomography images show multiple lung metastases. b: After two cycles of chemotherapy with carboplatin and paclitaxel, all lung metastatic nodules regressed. 
Ota et al:: Successful Treatment with Taxane-Based Chemotherapy in Advanced

Sebaceous Carcinoma: A Case Report and Literature Review

Table 1. Case reports of systemic chemotherapy for sebaceous carcinoma

\begin{tabular}{|c|c|c|c|c|c|c|c|}
\hline Author (year) & Sex & Age & $\begin{array}{l}\text { Primary } \\
\text { lesion }\end{array}$ & Chemotherapy & $\mathrm{RR}$ & $\begin{array}{l}\text { PFS, } \\
\text { months }\end{array}$ & $\begin{array}{l}\text { OS, } \\
\text { months }\end{array}$ \\
\hline $\begin{array}{l}\text { Koyama et al. } \\
\text { [6] (1994) }\end{array}$ & M & 47 & 0 & $\begin{array}{l}\text { Doxorubicin } 50 \mathrm{mg} / \mathrm{m}^{2} \text { and } \\
\text { Cisplatin } 75 \mathrm{mg} / \mathrm{m}^{2 * 1}\end{array}$ & PR & 7 & 7.8 \\
\hline $\begin{array}{l}\text { De Leo et al. } \\
\text { [7] (2006) }\end{array}$ & $\mathrm{F}$ & 42 & EO & $\begin{array}{l}\text { Cisplatin } 80 \mathrm{mg} / \mathrm{m}^{2} \text { and } \\
\text { Gemcitabine } 1250 \mathrm{mg} / \mathrm{m}^{2} \text { (every } 3 \text { weeks)*2 }\end{array}$ & PD & NA & 7.6 \\
\hline $\begin{array}{l}\text { Husain et al. } \\
\text { [8] (2008) }\end{array}$ & $\mathrm{F}$ & 50 & 0 & $\begin{array}{l}\text { Carboplatin and Docetaxel and } \\
\text { Bevacizumab (dose was not clarified) }\end{array}$ & PR & $\mathrm{NA}^{* 3}$ & NA \\
\hline $\begin{array}{l}\text { Joshi et al. } \\
\text { [9] (2012) }\end{array}$ & M & 21 & EO & $\begin{array}{l}\text { Carboplatin (AUC5) and } \\
\text { Paclitaxel } 175 \mathrm{mg} / \mathrm{m}^{2} \text { (every } 3 \text { weeks) }\end{array}$ & $\mathrm{CR}$ & $6^{* 4}$ & NA \\
\hline \multirow[t]{2}{*}{$\begin{array}{l}\text { Jung et al. } \\
\text { [10] (2013) }\end{array}$} & M & 66 & 0 & $\begin{array}{l}\text { Cisplatin } 75 \mathrm{mg} / \mathrm{m}^{2} \text { and } \\
\text { 5-FU } 750 \mathrm{mg} / \mathrm{m}^{2} \text { (daily for } 5 \text { days) } * 5\end{array}$ & response & NA & $\mathrm{NA}^{* 6}$ \\
\hline & $\mathrm{F}$ & 59 & 0 & & response & $\mathrm{NA}^{* 7}$ & NA \\
\hline $\begin{array}{l}\text { Orcurto et al. } \\
\text { [11] (2014) }\end{array}$ & M & 69 & EO & $\begin{array}{l}\text { 5-FU } 750 \mathrm{mg} / \mathrm{m}^{2} \text { (daily for } 4 \text { days) and } \\
\text { Cisplatin } 100 \mathrm{mg} / \mathrm{m}^{2} \text { and } \\
\text { Docetaxel } 75 \mathrm{mg} / \mathrm{m}^{2} \text { (every } 3 \text { weeks) }{ }^{* 8, * 9}\end{array}$ & $\mathrm{CR}$ & $20 * 10$ & NA \\
\hline $\begin{array}{l}\text { Kumar et al. } \\
\text { [12] (2015) }\end{array}$ & $\mathrm{F}$ & 81 & 0 & $\begin{array}{l}\text { FOLFOX [oxaliplatin, 5-FU, } \\
\text { and leucovorin] }{ }^{* 11}\end{array}$ & SD & 5 & 17 \\
\hline Present report & $\mathrm{F}$ & 80 & 0 & $\begin{array}{l}\text { Carboplatin (AUC5) and } \\
\text { Paclitaxel } 200 \mathrm{mg} / \mathrm{m}^{2} \text { (every } 3 \text { weeks) }\end{array}$ & PR & 11 & 18 \\
\hline
\end{tabular}

O, ocular lesion; EO, extraocular lesion; RR, response rate; PFS, progression-free survival; OS, overall survival; M, male; F, female; PR, partial response; PD, progressive disease; SD, stable disease; NA, not available; AUC, area under the curve; 5-FU, 5-Fluorouracil. ${ }^{* 1}$ Treatment schedule was not clarified. ${ }^{* 2}$ In this case, docetaxel $\left(25 \mathrm{mg} / \mathrm{m}^{2}\right)$ weekly and 5-FU $200 \mathrm{mg} / \mathrm{m}^{2}$ daily were administered as the second-line treatment. ${ }^{* 3}$ The patient underwent subtotal resection and radiotherapy for target lesion following chemotherapy. ${ }^{* 4} \mathrm{At}$ the time of reporting, the remission had been stable for 6 months. ${ }^{*}$ Chemotherapy interval was not clarified. ${ }^{* 6}$ At the time of reporting, the patient was under supportive care at 15 months after initial chemotherapy. ${ }^{* 7}$ At the time of reporting, 3 months after initial chemotherapy, the patient was due for the fourth cycle of chemotherapy. ${ }^{* 8}$ Due to myelosuppression, the decision was made to remove docetaxel from the regimen after the first cycle. ${ }^{* 9}$ Treatment was subsequently maintained with single-agent capecitabine $\left(1,000 \mathrm{mg} / \mathrm{m}^{2} / \mathrm{day}\right) \mathrm{on}$ days $1-10$ every 3 weeks. ${ }^{* 10}$ At the time of reporting, the remission had been stable for over 20 months. ${ }^{* 11}$ At the time of reporting, the patient was undergoing chemotherapy with paclitaxel at the second-line and gemcitabine at the third-line chemotherapy. 